Journal Plus Education, ISSN: 1842-077X, E-ISSN (online) 2068-1151 Vol XIX (2018), No. 1. pp. 273-280

\title{
METHODOLOGIES AND METHODS OF BUILDING ASSESSMENT QUESTIONNAIRES IN THE SPSM PROJECT
}

\author{
Mihaela GAVRILA-ARDELEAN, Ph.D. \\ Faculty of Educational Science, Psychology and Social Work, \\ „Aurel Vlaicu" University of Arad, Romania \\ miha.gavrila@yahoo.com \\ Laurence FOND-HARMANT, Ph.D. \\ Luxembourg Institute of Health, \\ Department of Population Health, Luxembourg \\ laurence.fond-harmant@lih.lu
}

Abstract: Santé Publique, Santé Mentale, Employabilité en Europe (SPSM), is a European Project developed by francophone countries in: 2014-2017. Through the project, training modules for professionals have been built. The aim of the research is to present the methodologies employed to construct evaluation questionnaires, and the methods used to built statistical grids in SPSM Erasmus + Project.Research methods: the evaluation of the SPSM Project was realized after the construction of Knowledge Assessment Questionnaire for Occupational Insertion Professionals for people with chronic mental diseases, and the other one is: Project Management Assessment Grid. First scale is a questionnaire comprising 24 items. It assesses the level of knowledge before and after the training module (Pilot Seminar). This procedure allows us to compare groups of items. The results are 2 questionnaires applied in the project assessment. The obtained results have enabled professionals to improve their skills through better course content.

Key words: questionnaire; methods; methodologies; project; evaluation;

\section{Introduction}

The questionnaire is a secondary tool of sociological investigation (Miftode, 1982; King, 2005). The methodological approach towards the elaboration of the questionnaires within this European project has been carried out on the basis of the need to assess the level of knowledge of 
professionals in the field of occupational integration of people with chronic mental diseases (Gavrila-Ardelean et al., 2016).

The social problem that has been analyzed is the reduction of the costs of handicap in mental disorders (Villotti et al., 2012, 2014 in GavrilaArdelean, 2017). This has been achieved through occupational integration of people with chronic mental diseases, with the aid of support specialists. Work is a social and economic utility in itself, for all people, especially for patients with chronic mental disorders, for whom it has psychotherapeutic functions, by increasing self-esteem and social utilities (Gavrila-Ardelean, 2016). Mental health and occupational integration of psychiatric patients have been studied in a synthetic study of the specialized bibliography. Moreover, the needs of three categories of actors involved in the research: beneficiaries, professionals, entrepreneurs, have been studied through questionnaires. (G.,Kelemen, 2017)

The questionnaire, as a technique and as a psychosocial investigation tool, consists of a set of written questions that are ordered logically and psychologically, and which, by self-administration, have determined answers in the investigated group, that have been recorded in the virtual environment (Cazacu, Bădescu, 1981; Chelcea, 1975; Mellenbergh, 2008). The questionnaire was written, computerized, and online administered in the Google documents system. The questionnaire has standardized answers on an graded scale, that facilitate the compilation of statistical data (Durkheim, 1974). In the SPSM Project, the questionnaires have been built on multi-item scales, thus allowing a quantitative collection of data.

The construction methodology of psycho-sociological questionnaires, on multi-item scale consists of (Robinson, 2017):

- Multiple questions for each examined variable (Fulger, 2010);

- An accompanying set of equal response points for each question (indicators, usually 5 or 7), (Miftode, 1982);

- An accompanying verbal anchor for each response ("disagree": 1 - 5: "strongly agree"), ascending in intensity (from left to right), (Norman, 2010);

- A gradual rating scale, as the Likert scale (Likert, 1932);

- The psychometric scale, a multi-element scale used when multiple items measure the same valid variable (Kaplan, Saccuzzo, 2009);

- A factorial analysis (King, 2005).

The multi-item scale must establish internal reliability and test-retest reliability. The psychometric scale requires construction validity and criterion validity (Kaplan, Saccuzzo, 2009). 
The questionnaires used for the collection of quantitative data usually include multi-element successive scales, an introductory section, and a section for concluding the questionnaire (Foddy, 1994).

\section{General issue}

The project Santé Publique, Santé Mentale, Employabilité en Europe (SPSM), is a European Project developed by francophone countries in: 20142017.

The aim of the project is to improve professional competences for a better occupational integration of people with chronic mental diseases. Through the project, training modules for professionals have been built. The classes were structureted on a week of training for each partner country in the SPSM Project. The content of the classes was built according to a complex analysis of the needs of occupational insertion professionals, beneficiaries and employers in each country participanting in the project.

The SPSM Project was evaluated through the Knowledge Assessment Questionnaire for Occupational Insertion Professionals. This scale is a questionnaire comprising 24 items. It evaluates the level of knowledge before and after the Pilot Seminar. This procedure enables us to make comparisons by groups of items, for a better course content (Allen, Christopher, 2007).

\section{Research Methodology}

The research methodology consists in building the tools needed to evaluate the results of the SPSM Project, based on specific methods of sociological research. Two evaluation questionnaires have been built. One of them is: Knowledge Assessment Questionnaire for Occupational Insertion Professionals, and the other one is: Project Management Assessment Grid.

As a sociological research method, the questionnaires comprise multiple questions. Each item has been appreciated by marking an answer, so as to assess the level of knowledge of the respondent. The subject's answers are of estimative type (subjective appreciation) of the level of knowledge, on a graded scale from left to right, from 1 (no knowledge) to 4 (very good level of knowledge).

The Knowledge Assessment Questionnaire for Occupational Insertion Professionals has been built on 24 questions.

The Project Management Assessment Grid was constructed from questions from 5 areas of items and remarks. The scale of appreciation was graded from left to right, from 1 (poor appreciation) to 5 (very good appreciation).

The questionnaires have been computerized and online administrated (Kaplan, Saccuzzo, 2009; Mellenbergh, 2008). 
Journal Plus Education, ISSN: 1842-077X, E-ISSN (online) 2068-1151 Vol XIX (2018), No. 1. pp. 273-280

\section{Research results}

The questionnaires are completely anonymous, and enable the assessment of the impact of the pilot seminar on the participants.

The working instructions required the subjects to mark with an $\mathrm{X}$, on a scale of 1 (no knowledge) to 4 (very good level of knowledge), their level of knowledge before and after the training.

In this questionnaires, the persons accompanied at the workplace are designated by the words "users" or "beneficiaries".

The Knowledge Assessment Questionnaire for Occupational Insertion Professionals is composed of the following items:

a) Country of the participant;

b) Level of degree;

c) Number of years of professional experience;

d) Estimated level of knowledge about employment and unemployment measures for people with mental handicap in local context: economic, legislative and social;

e) Level of knowledge about the local employment market, and business obligations and rights;

f) Estimated level of knowledge on the local social context, labor law, minimum wages, types of contracts, and the role of trade unions, for people with mental handicap;

g) Level of knowledge of the impact of mental diseases on the behaviour of beneficiaries at workplace;

h) Level of awareness of warning signs for a good prevention of crisis and level of knowledge of psychotropic treatment;

i) Level of knowledge about occupational insertion: limits, content of relevant information, links with the employer, and medico-psycho-socio referents;

j) Estimated level of knowledge of the enterprises' methods of approach;

k) Level of knowledge on business: corporate culture, employers' constraints;

1) Estimated level of knowledge on the commercial marketing approach: techniques of building businesses, and prospecting and negotiating techniques;

m) The level of knowledge of multidisciplinary partners' network work;

n) Level of knowledge of the systemic approach, the place and the role of each part in the triptych: users, professionals in occupational insertion and enterprises;

o) Level of knowledge of the brakes and obstacles that may impede the improvement of the employability of users/beneficiaries;

p) Knowledge about the concepts of autonomy and self-determination; 
q) Knowledge needed to eliminate prejudice and to improve communication between employer-beneficiary-team, so as to facilitate the insertion;

r) Knowledge about the ways we can reduce stigma in order to improve the life of the beneficiaries;

s) Knowledge of recovery methods for beneficiaries;

t) Inclusion strategies;

u) Stress management methods;

v) Ability to analyse the competences of users/beneficiaries;

w) Estimated level of knowledge of coaching strategies and elements;

x) Expectations about the Pilot Seminar.

The Project Management Assessment Grid has evaluated 5 areas of items, within 28 questions, and final remarks. The scale of appreciation was graded from 1 (poor appreciation) to 5 (very good appreciation). The 5 areas explore the economic and administrative aspects of the management of the SPSM Project, along with the functionality of human resources (table 1).

Table no. 1. Project Management Assessment Grid

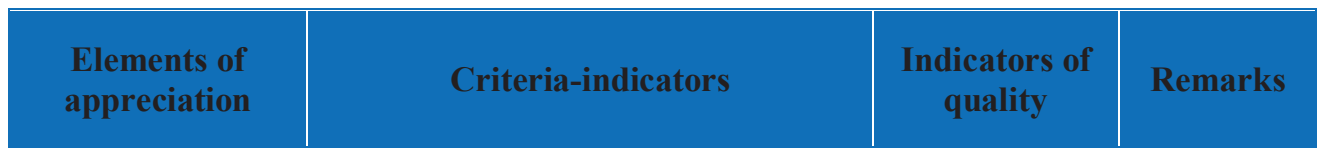

\begin{tabular}{|l|l|l|l|}
\hline 1. Public & $\begin{array}{c}\text { Number of registrants per pilot } \\
\text { seminar }\end{array}$ & $1-2-3-4-5$ & $1-2-3-4-5$ \\
& Frequentation - Assiduity & $1-2-3-4-5$ & $1-2-3-4-5$ \\
& Implication of trainers & $1-2-3-4-5$ & \\
& Implication of participants & General satisfaction & \\
\hline
\end{tabular}

\begin{tabular}{|l|l|r|r|}
\hline 2. Partnership & Composition & $1-2-3-4-5$ & \multirow{1}{*}{ Implication - Engagement } \\
& Satisfaction & $1-2-3-4-5$ & $-4-5$ \\
& Link to other European projects & $1-2-3-4-5$ & \\
\hline
\end{tabular}

\begin{tabular}{|c|l|c|c|}
\hline $\begin{array}{c}\text { 3. Informatio } \\
\mathbf{n} /\end{array}$ & Quality of information & $1-2-3-4-5$ & 1 \\
Communication & $\begin{array}{l}\text { Communication between partners } \\
\text { Communication between local } \\
\text { actors } \\
\text { Communication in the world of }\end{array}$ & $1-2-3-4-5$ & $1-2-3-4-5$ \\
& $1-2-3-4-5$ & \\
\hline
\end{tabular}


Journal Plus Education, ISSN: 1842-077X, E-ISSN (online) 2068-1151 Vol XIX (2018), No. 1. pp. 273-280

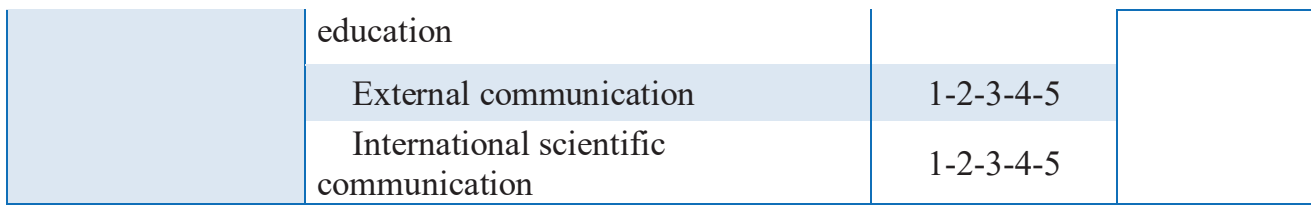

\begin{tabular}{|l|l|c|c|}
\hline $\begin{array}{l}\text { 4. Human } \\
\text { resources }\end{array}$ & $\begin{array}{l}\text { Repartition of the human resources } \\
\text { Adequacy of needs }\end{array}$ & $1-2-3-4-5$ \\
& Satisfaction of actors: & $1-2-3-4-5$ & \\
& Trainers & $1-2-3-4-5$ & \\
& Professionals & $1-2-3-4-5$ & $1-2-3-4-5$ \\
& Satisfactions of partners & \\
\hline
\end{tabular}

\begin{tabular}{|c|l|c|}
\hline $\begin{array}{c}\text { 5. Follow-ups } \\
\text { of the project }\end{array}$ & $\begin{array}{c}\text { Quality of the of project's } \\
\text { coordination } \\
\text { Following the schedule }\end{array}$ & $1-2-3-4-5$ \\
& Budgeting & $1-2-3-4-4-5$ \\
& Quality of the project's productions & $1-2-3-4-5$ \\
& Professionals' participation & $1-2-3-4-5$ \\
& Events and conferences & $1-2-3-4-5$ \\
& Intellectual productions & $1-2-3-4-5$ \\
& Scientific articles & $1-2-3-4-5$ \\
\hline
\end{tabular}

\section{Conclusions}

The questionnaire, as a sociological method of scientific research, has been succesfully applied in the SPSM European Project.

In the European context of employment crisis, and complexity of relationships between the economic world and the society, we rise to the challenge of proposing mental health training (Gavrila-Ardelean, GavrilaArdelean, 2015).

These two examples of questionnaires explore the level of training of occupational insertion professionals for people with mental diseases, along with the quality of European project management. The results of the questionnaires guarantee the quality of occupational insertion training, and establish transferable and accessible recommendations at European level, both at macro-political and micro-structural levels (Organisation of training and University), (Gavrila-Ardelean, et al., 2016). 


\section{References:}

Allen, E., Seaman, C. (2007). Likert Scales and Data Analyses. Quality Progress, 64-65.

Cazacu, A., Bădescu, I. (1981). Metode şi tehnici de cercetare sociologică, Universitatea din Bucureşti.

Chelcea, S. (1975). Chestionarul în investigaţia sociologică, Editura Ştiinţifică şi Enciclopedică, Bucureşti.

Durkheim, E. (1974). Regulile metodei sociologice, Editura Ştiinţifică, Bucureşti.

Foddy, W.H. (1994). Constructing questions for interviews and questionnaires: Theory and practice in social research (New Ed.). Cambridge, UK: Cambridge University Press.

Fulger, I.V. (2010). Metodologia cercetării în ştiinţele socio-umane partea a II - a, Centrul de multiplicare al Universităţii din Petroşani, Petroşani, Editura Universitas.

file:///D:/Metodologia $\% 20$ cercetarii $\% 20 \mathrm{in} \% 20$ stiintele $\% 20$ socioumane/Met odologia $\% 20$ Cercetarii $\% 20$ in $\% 20$ Stiintele $\% 20$ Socio-Umane.pdf

Gavrila-Ardelean, M., Gavrila-Ardelean, L. (2016). Elemente de medicina intena si sociala, Bucuresti: Eikon.

Gavrila-Ardelean, M. (2016). Reducing the Stigma of People with Mental Handicap. Agora Psycho-Pragmatica, 10(2), 39-45.

Gavrila-Ardelean, M., Fond-Harmant, L., Kelemen, G. (2016). The Improvement of the Counselors Competences for the Professional Integration of People with Mental Disorders. Asian Academic Research Journal of Social Science \& Humanities, 3(4), 29-40.

Kaplan, R.M., Saccuzzo, D.P. (2009). Psychological testing: Principles, applications, and issues. Belmont, CA: Wadsworth.

Kelemen Gabriela, Social and cultural contexts regarding mental health in Europe. Intervention strategies, Journal Plus Education, Vol 17, No 1 (2017)

King, R. (2005). Strategia cercetării. Treisprezece cursuri despre elementele ştiinţelor sociale, Editura Polirom, Iaşi.

Likert, R. (1932). A Technique for the Measurement of Attitudes. Archives of Psychology. 140: 1-55.

Mellenbergh, G.J. (2008). Chapter 10: Tests and questionnaires: Construction and administration. In Adèr H.G. \& G. J. Mellenbergh (Eds.) (with contributions by D. J. Hand), Advising on research methods: A consultant's companion, Huizen, The Netherlands: Johannes van Kessel Publishing, 211-234.

Miftode, V. (1982). Introducere în metodologia investigaţiei sociologice, Editura Junimea, Iaşi. 
Norman, G. (2010). Likert scales, levels of measurement and the "laws" of statistics. Advances in Health Science Education, 15(5): 625-632.

Robinson, M.A. (2017). Using multi-item psychometric scales for research and practice in human resource management. Human Resource Management. https://dx.doi.org/10.1002/hrm.21852 (open-access).

Villotti, P., Balducci, C., Zaniboni, S., Corbiere, M., Fraccaroli, F. (2014). An analysis of work engagement among workers with mental disorders recently integrated to work. Journal of Career Assessment, 22(1), 18-27; and Villotti, P., Corbiere, M., Zaniboni, S., \& Fraccaroli, F. (2012). Individual and environmental factors related to job satisfaction in people with severe mental illness employed in social enterprises. Work, 43, 33-41; in Gavrila-Ardelean, 2017. Personal Needs And Psycho-Social Expectancies Of People With Mental Chronic Disorders Regarding Professional Insertion, Revista de cercetare și intervenție socială, Expert Projects Publishing House, 56: 57-69. 